The Journal of Society and Media, October 2020, Vol. 4(2) 425-442

https://journal.unesa.ac.id/index.php/jsm/index

E-ISSN 2580-1341 and P-ISSN 2721-0383

Accredited KEMENRISTEK/ BRIN No.148/M/KPT/2020

DOI: 10.26740/jsm.v4n2.p425-442

\title{
Comparative Analysis of The Political Motivation of The Partisans Who Vote for D. Trump and V. Zelensky
}

\author{
Max Ratnikov ${ }^{*}$, Natalia Zemzyulina ${ }^{2}$ \\ ${ }^{1,2}$ Bohdan Khmelnytsky National University of Cherkasy, Ukraine \\ Email: mratnikov@gmail.com \\ Email: aklatan.zem@gmail.com
}

\begin{abstract}
The aim of this article was to reveal the motivation of partisan who vote for showmen which were elected to high government posts. Data collection was carried out using a combination of quantitative and qualitative methods. In the first case, a questionnaire (100 questionnaires) was used, in which people who had reached the voting age and voted for Zelensky and his party in the elections participated, followed by an in-depth interview. The study participants were recruited from different districts of the city of Cherkasy. As a result, the common and different in the electorate of D. Trump and V. Zelensky was revealed.
\end{abstract}

Keywords: elections, partisan, support, Zelensky, government

Paper type: Research paper

*Corresponding author: mratnikov@ gmail.com 2020-05-27; Accepted: 2020-10-29; Published: 2020-10-30

Cite this document: Ratnikov, Max, Natalia Zemzyulina, and N. Zemzyulina. (2020). Comparative Analysis Of The Political Motivation Of The Partisans Who Vote For D. Trump And V. Zelensky. The Journal of Society and Media, 4(2), 425-442. DOI: 10.26740/jsm.v4n2. 425-442 


\section{INTRODUCTION}

As a result of elections in the United States and Ukraine, in which there was a rise to power of political populists, there was a complex and extremely ambiguous problem. Namely, how to explain the victories of showman politicians in extremely difficult and competitive elections. The answer to this problem can help shed light on what tectonic shifts are taking place in societies at the present stage. The process of selecting leaders must promote democracy so that everything goes well (Pandiangan 2018). Democracy can be implemented with its cause in a state society that will produce a satisfied society. The involvement of voter behavior is strongly influenced by the atmosphere of existing political life. The politics of democracy and sosio-cultural life with its growth and deveploment (Fauzi 2019).

This study expands the knowledge of the contemporary political and cultural landscape of Ukraine and the United States by examining the extent to which protest moods, namely the reflection of economic anxieties and uncertainty about the future, as well as the thirst for justice, become a source of desire for radical change. So that it gives birth to participants who work together in achieving leaders who meet the needs of the state (Praveen 2020). This leads to such a phenomenon, when the party "Servant of the people" is absent, and the rating present. We emphasize that the problem of winning by unexpected candidates from the world of show business gives additional complexity to the impossibility of using standard methods of explanation, so we should use another methodology.

In the framework of this study, we rely on a sample of a survey of citizens of Ukraine in Cherkasy, conducted shortly after the elections in the summer of 2019, which covered the question of choosing a vote in favor of V. Zelensky. As a result, we can take a closer look at how and in which way, along with other factors, economic uncertainty signals a real voting choice. In addition, while other sources of quantitative data after the election included limited measures reflecting opinion more about other political forces, our questions focused only on Zelensky's electorate. As our data also contains details in relation to gender issues, immigrants, and economic discontent, we are better able to distinguish between some of the independent consequences that lead to political change. 
Structurally, this work consists of several sections. Introduction, where we briefly reveal the essence of the problem. In the second section we have methods, in which there is a description of the logic of building a survey. Then we logically follow the results, in which the statistics of the answers are revealed. The novelty, in the discussion section, we will answer the question of why voters are so ready to believe the man from the TV screen, who has not yet shown himself in politics. The last section we have conclusions, which will generalize the results. This is also related to population growth in 4.0, which brings participants to think about their future.

\section{METHOD}

According to the generally accepted theory of elections, the behavior of the voter in any country can be predicted by having information about his/her eight main characteristics (Mucciaroni 1992; Norris and Inglehart 2019):
a. age
b. sex
c. financial position
d. marital status
e. education
f. point of view on topical political problems,
g. assessment of the current state of affairs in the country
h. assessment of the current government.

We proceeded from the fact that it is necessary to supplement this data with questions about the attitude to the family and marriage, as well as purely economic issues. Also, it was important for us to find out how long their memory is. Therefore after standard questions there was a qualitative interview that would define more precisely a vital picture of V. Zelensky's voter. The aim of the empirical study was to identify the motives for voting for Zelensky. It could be that the leadership model is seen from the context of the speech text. Second, why this speech text can be produced can be seen from its cognition and social context (Chakim 2018, Farida, Indah 2018). 
Data collection was carried out using a combination of quantitative and qualitative methods. In the first case, a questionnaire (100 questionnaires) was used, in which people who had reached the voting age and voted for Zelensky and his party in the elections participated, followed by an in-depth interview. In order to capture the many views of voters on the social and economic causes of voting in a major city of Ukraine, a qualitative study design with semi-structured interviews was used.

Technically, a qualitative research interview is semi-structured, since it is not a free conversation, but it is not a highly structured questionnaire either. It follows a set pattern, focuses on specific topics, and may include specific recommended questions (Kvale 2006). To ensure the representativeness of the sample, the study participants were recruited from different districts of the city of Cherkasy. A total of 100 interviews were conducted: 59 of them with women aged 18 to 47 years, the average age of the study participants is 32.7 years and 41 interviews with men aged 41 to 56 years, the average age of the study participants is 49.8 years. Selection criteria: people who have reached the voting age and voted in the elections for Zelensky and his party. Participants expect from Zelensky and D Trump for an agreement related to responsibilities and obligations as leaders of the country (Dzikirrullah 2018).

To obtain complete and in-depth descriptions of the different views of the study participants, qualitative content analysis was chosen as an analytical method. Qualitative content analysis aims to identify the content and messages in texts, a process that involves multiple readings of the text and identifying elements of meanings or episodes according to the objectives of the study. The meaning elements and episodes were compressed and further reduced to codes, which were finally grouped into categories and subcategories based on similarities in the content said in the interview (Finfgeld-Connett 2014). Time and geographical scope of sociological research: August 2019 Cherkassy.

Our sample allows us to draw certain conclusions, since it is assumed to be homogeneous. As classic sociology states, a conclusion about the state of health can be made by a few drops of blood analyzed in a laboratory. This method is based on the assumption that the circulating blood is always well mixed and each drop carries the same information. This is exactly the logic we had when forming the sample. We limited the respondents to residents of Cherkashchenya, which 
allowed us to summarize faster, for less cost and within shorter time than with other inputs. The presence of support from each of these Presidential candidates was motivated by the proximity of members and regional similarities (Setiawan dan Khotimah 2018).

According to the theory, sample surveys have a wider scope and provide a greater opportunity to obtain information of a very diverse nature. Therefore, a sample survey can provide more reliable information than a corresponding full survey. On the other hand, if accurate information about small groups in the original population is desired, the sample size required may be so large that a complete census is preferable.

Major figures of classical sociology of the twentieth century note that sample research can be conditionally divided into two types: descriptive and analytical. The purpose of a descriptive survey is simply to obtain information about some large groups, such as the number of men, women, and children who, for example, watch a particular television program. The analytical one compares the various subgroups of a population in order to establish whether there are differences between them that would allow us to construct or test hypotheses about the nature of the forces acting in a given population, so we have more analytical than descriptive. At the same time, the main thing is that the population from which the selection is made (the surveyed population) coincides with the population about which we want to collect information (the studied population).

At the same time, we note that the results of sample surveys are always somewhat uncertain. This happens because only a part of the entire population is examined and measurements are made with acceptable errors. For samples of the size that is usually found in practice, there is often every reason to believe that the sample estimates have an approximately normal distribution. For normally distributed estimates, the frequency distribution is fully known if the mean and standard deviation (or variance) are known.

\section{RESULTS AND DISCUSSSION}

The first thing we have established is that the priorities and attitudes of the electorate of $\mathrm{V}$. Zelenskyare connected with the modern egalitarian model of justice based on: 
a. fair, proportional division of responsibilities between the bodies of the institutions of power $(87 \%)$;

b. interchangeability of politicians in solving social and economic problems $(76 \%)$;

c. collective discussion of the main problems and joint adoption of important decisions for the state $(87 \%)$;

d. equal contribution to the replenishment of the state budget (56\%) and its order $(63 \%)$.

Table 1

Distribution Of Respondents' Answers To The Question

“Who In The State Should Perform Certain Roles And Responsibilities?”, \%

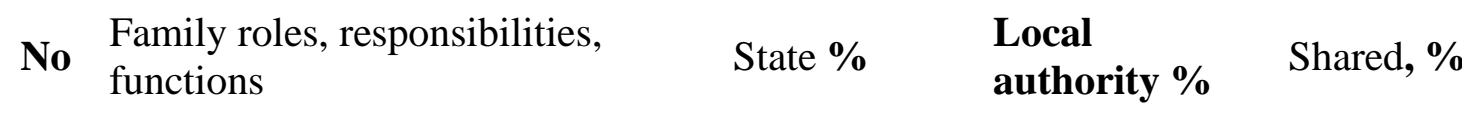

\begin{tabular}{lllll}
\hline 1 & Defense & - & 24 & $\mathbf{7 6}$ \\
2 & Minor repairs & $\mathbf{1}$ & $88-$ & 11 \\
3 & Replenishment of the state budget & 41 & 3 & $\mathbf{5 6}$ \\
4 & Disposal of the state budget & 17 & 18 & $\mathbf{6 5}$ \\
5 & Bringing back the territory & 88 & $\mathbf{1}$ & 11 \\
6 & Taking care of refugees & - & - & $\mathbf{1 0 0}$ \\
\hline
\end{tabular}

Secondly, among the electorate of V. Zelensky, attitudes to creative, constructive family values that contribute to the achievement of universal values, as well as those values of the family, which in this culture are considered generally accepted, prevail:
a. the love of spouses $(78 \%)$;
b. love for children $(99 \%)$;
c. mutual understanding (100\%);
d. loyalty (78\%);
e. responsibility $(64 \%)$;
f. good and warm relations of relatives (34 \%);
g. family comfort (89\%). 
Ratnikov: Comparative Analysis Of The

Political Motivation Of The Partisans

Who Vote For D. Trump And V. Zelensky|431

Table 2

Distribution Of Respondents' Answers Regarding Family Values, \%

\begin{tabular}{|c|c|c|c|}
\hline $\begin{array}{l}\text { № } \\
\text { ㅍ/II }\end{array}$ & Variant of answers & $\begin{array}{l}\text { the Degree of } \\
\text { importance of }\end{array}$ & $\%$ \\
\hline 1 & Childbearing & 1 & $14 \%$ \\
\hline 2 & $\begin{array}{l}\text { Value of health and healthy lifestyle of } \\
\text { the family }\end{array}$ & 2 & $13 \%$ \\
\hline 3 & $\begin{array}{l}\text { Raising children in an atmosphere of } \\
\text { love }\end{array}$ & 3 & $12 \%$ \\
\hline 4 & Love and understanding between spouses & 4 & $11 \%$ \\
\hline 5 & $\begin{array}{l}\text { The value of intra family } \\
\text { communications }\end{array}$ & 5 & $11 \%$ \\
\hline 6 & Support the life of family members & 6 & $10 \%$ \\
\hline 7 & $\begin{array}{l}\text { Values availability of relatives (brothers, } \\
\text { sisters) }\end{array}$ & 7 & $10 \%$ \\
\hline 8 & Many children & 8 & $9 \%$ \\
\hline 9 & Value of equality of spouses & 9 & $6 \%$ \\
\hline 10 & Family based on legal marriage & 10 & $4 \%$ \\
\hline
\end{tabular}

Thirdly, among the supporters of V. Zelensky there is a lack of knowledge about the powers of state officials and political culture, which creates contradictions in political orientations, reflecting the contradictions between knowledge and behavioral attitudes. Thus, the knowledge in the issues of the separation of power of the Cabinet of Ministers and the office of the President is shallow or absent, which indicates the demand and closer attention of specialists to this problem. According to the results of the study, the problematic issues on which the Zelensky's electorate is missing knowledge or this knowledge is shallow are: budget awareness; issues of rights and obligations in public administration; issues of constructive conflict resolution in public authorities and others.

Fourth, the desire to build a career, to acquire financial independence and independence, uncertainty about the future affect the choice for V. Zelensky. Thus, $56 \%$ of respondents noted that the optimal candidate for a politician is someone who is young, successful, recognizable and has never been in politics.

Further after this question there was a qualitative interview. A common reason for choosing to vote for $\mathrm{V}$. Zelensokgo, both for men and women, is the 
economic failure of the authorities, their inability to provide material support for the citizen. The transformation period and the economic crisis have exacerbated this problem for men now aged 50 and over, as they received vocational education and first work experience in the specialty during the Soviet Union era, then many were unable to adapt to the new conditions and as a result do not have a permanent job and stable earnings. Study participants from among men over the age of 50 often pointed out this problem.

"We have always lived hard. Socially, we have changed the relationship between generations of people. The world has changed, and adults have remained with their concepts, we began to live in an era of change. The changes are very strong, terrible, very unpleasant. Many people did not survive in this situation".

"After the collapse of the USSR, when the factories and plants in Cherkasy collapsed, a lot of young people, skilled workers who worked there, were left without work. Many have not been able to settle well, now where are they? Trade in the market or wash dishes".

"We have no crisis because there is no crisis anywhere in the world, we have uncertainty. Mess in the economy. The economic crisis is when there is production, when there is commodity and material values, but when something does not go. We have nothing. Cherkasy used to be an industrial city. I worked in a factory, it's a textile factory. What did they do with such a powerful plant - put a trading house".

The understanding of responsibility and conscious choice for V. Zelensky was noted by the data on their life goals: voters associate their future with children, aim to raise and provide financially for their children without forced immigration, take care of grandchildren. Most of the study participants did not mention personal achievements, personal growth goals, personal life structure, career growth. 
"I want to raise my son, buy him a house and a car. My future is just that, I don't think about anything else. I'm thinking of getting him married, buying a house for him. I'll look after my grandchildren myself".

"The meaning of life is in children. The Kazakhs say if you have no children, then the fate did not work out, you were left alone, and you will die alone, and after the death of such a person did not leave offspring”.

"I don't want to make a career. Only child. The most important thing for me is to raise a child and that's all".

"To a greater extent, I want to dedicate my life to the child. At this time, all I have in mind is that my child will get an education and create a family".

Supporters of V. Zelensky do not want to go to immigration because they fear that they will have to choose between family and work. That also speaks of self-restraint in the realization of personal family well-being. As a result of constant self-restraint, voters.

"The strongest deterrent is fear, neither money nor time. Fear in general. I used to live with a sense that I was wrong. And if it's good - I'm scared of it. Sometimes, it seems, it is better to let it be as it is. I understand that a lot is imposed on me from my parents, I absorb like a sponge everything from society, a lot is imposed on me from my own wrong judgments. Fear is there, it needs to be analyzed and killed".

Many study participants expressed the opinion that they are not protected socially, that working people do not need the state - no benefits, no compensation, no public assistance, "there is at least some social support, to feel that you are a citizen of this society and that there is support from the state for you." Thus, especially those with lower levels of education and fewer skills continue to face precarious employment, low wages and high levels of poverty. The results of our study also showed that V. Zelenskiy's voters are people with a low level of education, who do not have professional education, do not have a stable job, and earn through temporary part-time or casual earnings. Often, such employment is not formalized by an employment contract, which leads to infringement of rights. 
"Now it has become more difficult to find a job, people are less asking to make repairs. Accordingly, this affects me and my work. Beats on pocket. We have to look for different part-time jobs".

"Constantly thinking where to get money, where to earn money, save money".

On the basis of our survey, we can draw conclusions about country features. For example, Trump made the main emphasis on domestic policy also because there was a consolidation of the new conservative majority (Oliver and Rahn 2016), which we cannot see in Ukraine. However, the common feature for both the United States and Ukraine is not the properties of political cycles, but the evolution of the composition of legislative bodies.

The 2016 - 2020 elections showed that the central voter was missing in both countries (Kennedy et al. 2018; Pierson 2017). One of the side effects of the President's broad electoral base in both Ukraine and the United States is that voters are often very different ideologically even within the same social group. The only thing they have in common is a protest vote (De la Torre 2017). Thus, we can assume that such politicians as D. Trump and V. Zelensky can win only in conditions of electoral fragmentation.

Voters of such a politician like to watch fascinating but pseudo-politics no matter what awaits them (Hall, Goldstein, and Ingram 2016). The content and meaning of political statements to voters are not very important, as they are judged by changes on the ground. It is important for them to make their views intelligible and a strong, unambiguous, sharp and distinct expression of the political position. In most democratic countries, citizens vote voters have the opportunity to vote them for several political offices (Fauzi 2018). A strategy is needed by presidential candidates to attract public participation (Fauzi 2018).

The importance of this political element leads us to the conclusion that under showman politicians, voters who are at the center of public policy are clearly not the most benevolent people. It is on the basis of their views that state priorities and the political agenda are formed, which makes the political line of politicians unyielding.

At the same time, one should not lose contact with such a voter, at least because he has a short memory, and therefore politicians of the populist era retain the same style of behavior as they did during the election campaign. It is this 
Ratnikov: Comparative Analysis Of The

Political Motivation Of The Partisans

Who Vote For D. Trump And V. Zelensky|435

practical consideration that can explain that the manners of D. Trump remain in the White House, and V. Zelensky immediately conducts one electoral campaign after another. This tactic consists in messages full of optimism and patriotism, designed for a wide range of voters and able to give faith in themselves to any member of the social grassroots. Including in politics, the existence of Political Branding some of which were made in a positive jargon, but some are made with negativity, the second aimed to create negative effects for political opponents (Fauzi 2016).

The main motive for voters in Ukraine and the United States is economic problems. If we take the classics of American social thought, namely the Radical Right: A Problem for American Democracy Seymour Martin Lipset (Lipset 1955), he noted that the increased competition for good, sustainable jobs in an era of shrinking middle class creates relentless pressure on the white working class, which boldly begins to struggle with the violation of family norms and lower wages. Only in 1955 were blacks a threat, and now it's nonwhites and nonChristians (Whitehead, Perry, and Baker 2018), especially Mexicans and Muslims. In Ukraine, the economic fears associated not so much with immigration, but how much with the need to become immigrants themselves.

At the same time, we can fix the differences. Sociologists describe a typical Trump follower as a white male who is typically engaged in manual labor with hourly pay (Wang et al. 2017). One study found that Trump won the support of 50 percent of voters who earn less than $\$ 50,000$. But it's a fact: trump has very often won in districts where, by all measures, the median income was at least $\$$ 72000 , higher than the average than Clinton $(\$ 56,000)$ and higher than Sanders $(\$$ 61,000) (Hochschild 2016). This completely negates the theory that only social outsiders vote for him.

In this case, the question arises: since he unites such different groups of voters, what is the secret of such a politician? Maybe the secret to success is that specifically Trump, behind his guise of a clown and a hypocrite, simultaneously raises important questions? For example, should the federal government really help everyone? Anyone? Firms or just people? Should modern white Americans pay the price for racial discrimination of the 60s? Should they be strangers on their own land? 
Major expert on Trump supporters Arlie Russell Hochschild argues that we are witnessing a very broad reformatting of the Republican party, where angry people have created within one party a group that will fiercely defend their interests (Hochschild 2016). D. Trump for the voter is a Big Deal, or to put it in scientific language, Trump offers himself as a personal messenger in the power of his followers. Its electoral base is cross-social, i.e. one that is not characteristic of a single social group. Just as fans of Kim Kardashian are among the rich and among the poor, just as voters of D. Trump are among the rich and among the poor.

That is why a TV star (in fact, there are a lot of people who came from the screen to the world of American politics (for example, ex-senator Scott Brown)), and a billionaire (the second case in the history of the United States), who says clearly not the most expected things from Americans, became President. At the same time, he has an abnormally high level of support among Americans. It was candidate, who set records for the number of donations to campaign activities among Republicans. This is especially surprising in light of the polls, according to which his electorate is not inclined to give money to other people purely for ideological reasons.

Some political scientists, such as, for example, a lecturer at Yale University and at the same time a columnist for the New York Times, David Brooks, argue that Trump's support is a direct consequence of economic decline, especially among working-class white Americans (Brooks 2018). We believe that this assumption is consistent with social reality, the essence of which will be explained below.

Most illegal immigrants do not pay income taxes, resulting in billions in deficits. The taxes that will be paid will go to the federal budget, not to the local one. This is an important point, as the main funding for police, fire services, schools and hospitals comes from local budgets. The problem of social dependency is poorly understood by foreign commentators and well understood by conservative residents of the South of the United States, whose interests are expressed by D. Trump, trying to build a wall (Pettigrew 2017).

Among other things, the flow of illegal immigrants reduces wages in the manufacturing and construction business. However, this does not have a positive economic effect for the average American, since the fall in wages is good only for 
the export economy, but not for the US, which imports itself (Dixon, Johnson, and Rimmer 2011).

The next social fact: illegal immigrants do not work on jobs, on which Americans do not work. Under U.S. law, workers must adhere to the same wages and labor laws. When cheap labor dominates the market, wages go down for everyone regardless of nationality.

We should emphasize this factor. When wages fall, American workers and the poorest suffer first, because the poverty gap increases precisely because of the wage gap. This decline of the working class leads to the fact that people are willing to vote for someone who will simply voice what they see on the ground (Olney 2018).

The views of white workers are reflected in Trump's rhetoric, if you carefully read his statements to voters, not to the press. This is where his first message - the level of real production in the United States is not growing for 15 years. Hence the second message - according to Trump, the US government is deceiving ordinary workers by allowing TNCs to earn on cheap China, and that is why all senior staff of the presidential administration will have to sign a contract according to which they will not be able to work in private companies for 5 years from the moment of dismissal.

The next reason for Trump's popularity, the authors call people's anger at the policies of the existing political liberal establishment, which rejects the traditional way of life (Faber et al. 2017). If economic policy is a real threat to the redistribution of resources among US social groups, the rejection of traditional policies is a symbolic threat to "white American values". This is a very important point, as before for decades it was believed that white concerns about their status is not important for politics in the United States, but clearly not now.

More than 150 years before, the white fear factor about their position did not play a key role in elections. The last time was before the civil war. Lyndon Jones's policies cannot be cited as an example, because there was no tendency for whites to decline back then.

Such a shift in views according to socio-psychological theories of identity and intergroup relations forces voters to support more conservative political positions and will bring to the agenda with the rhetoric of such a politician as we 
see in D. Trump. Since he was the most active in words and actions towards Muslims and illegal immigrants from Latin America (i.e. he considered the status characteristics of people), then became especially attractive to all those who are concerned about the decline of the position of whites in American society and who often perceive "reverse discrimination" too painful.

Rhetoric with a ton of criticism and without political correctness makes D. Trump a particularly attractive candidate for people who are uncertain about the future.

If the strength of a leader's appeal lies in the need of those who have reached out to him, then we also, following Arlie Russell Hochschild (Hochschild 2018), believe that one of the foundations of Trump's success is that he has become the leader of these social groups.

Unlike D. Trump, V. Zelensky got a huge, free, unoccupied political niche of ordinary people who are tired of political hysteria and confrontation. They as well as D. Trump's electorate are cross-social i.e. such which are not characteristic for any unique social group, or an explicit geographical location.

The most paradoxical thing is that within the framework of the vote, an unprecedented alliance of electoral groups of moderate political views emerged for Ukrainian politics. The process of social choice in which the voter has to make a strange path in his head from rejection of the authorities to the decision to support the actor, and for example, not to come to the polls, requires a separate study.

One of the side effects of Zelensky's broad electoral base is that his voters often differ very much ideologically and in many assessments of current issues do not overlap. However, at the same time, each group of voters manages to see something of their own in it and at the same time something not to see pointblank.

Due to the fact that V. Zelensky was not perceived as a real candidate for a long time, he avoided reputational attacks (Peisakhin and Rozenas 2018). As a result, he had no alternative in the role of "non-politician", also departed the voices of all those who are tired of the rhetoric of Poroshenko, Tymoshenko and all the fragments of the former party of regions and considers Zelensky as the closest to himself of all the real candidates. 
This stage in the social development of Ukraine will lead to a complete reset of the political system, which cannot be stated in the United States (Wellman, Hyde, and Hall 2018). We can note that within the framework of American political processes, the system of checks and balances, as well as a higher level of institutional development, were able to prevent the development of crisis trends. During the reign of V. Zelensky, the constitutional crisis came on the first day.

\section{CONCLUSION}

The arrival of new forces is a reflection of the change in the structure of productive forces in Ukraine. If in 2013 the society of Ukraine had a relatively stable polarized structure and a clear geographical stratification, after 2013 came fragmentation, which made the country an international donor of commodities and human potential.

Such a society is no longer interested in the articulation of interests, which can be called "representatives of the Maidan". The change in values has made voters more concerned about poverty than corruption, personal development than national interests, high prices and expensive tariffs rather than the complexity of integration. The past agenda causes either apathy or rejection, thus the pattern of voters has changed from an emphasis on program postulates to an emphasis on purely personal qualities.

Thus, if policy in the U.S. - a process through which selective core current president is determined by the relationship between the directions of expenditure of the state in terms of existing resources, in Ukraine a new round of transition from the soviet legacy to more modern forms of operation.

Also, if you follow this logic, the elections of 2016 in the United States and 2019 in Ukraine - a milestone in social development, which will lay new factors in the policy of countries, regardless of what happens next. 


\section{REFERENCES}

Brooks, David. 2018. “The Chaos after Trump.” New York Times.

Chakim, Abdul. 2018. "Discourse Deputy Regent of Sampang In 2017 Musrembang Leader." The Journal of Society and Media 3(1).

Dixon, Peter B., Martin Johnson, and Maureen T. Rimmer. 2011. "Economy-wide Effects of Reducing Illegal Immigrants in US Employment." Contemporary Economic Policy 29(1):14-30.

Dzikirrullah. 2018. "Memaknai Hak Dan Kewajiban Dalam Kebijakan KerjasamaSwasta Dengan Pemerintah Daerah.” The Journal of Society and Media 33(1).

Faber, Daniel, Jennie Stephens, Victor Wallis, Roger Gottlieb, Charles Levenstein, Patrick CoatarPeter, and Boston Editorial Group of CNS. 2017. “Trump's Electoral Triumph: Class, Race, Gender, and the Hegemony of the Polluter-Industrial Complex."

Farida, Indah, Sultan. 2018. "Relasi Sosial Dalam Praktik Kebijakan CSR." The Journal of Society and Media 3 (1).

Fauzi AM. 2018. "Maintaining Identity Political Culture In Indonesia." The 2nd International Joint Conference on Science and Technology (IJCST).

Fauzi, Agus Machfud. 2016. "Jokowi's Political Branding For the Victory of the President.” Departement of Social Science - Social Science and Law Faculty Universitas Negeri Surabaya (Politic, Election, Branding, Victory).

Fauzi, Agus Machfud. 2018. "Pengembangan Integrasi Sidalih Antara Pilwali Surabaya Dan Pilgub Jawa Timur: Optimalisasi Pelayanan Publik KPU Kota Surabaya." JPSI (Journal of Public Sector Innovations) 3 No 1(PILGUB; PILWALI; Pemilih; Sidalih; demokrasi lokal).

Fauzi, Agus Machfud. 2019. "Perilaku Pemilih Menjelang Pemilu 2019.” Journal of Islamic Civilization 1 No 1(Perilaku, Pemilih, Politik, Pemilu):40.

Finfgeld-Connett, Deborah. 2014. "Use of Content Analysis to Conduct Knowledge-Building and Theory-Generating Qualitative Systematic Reviews." Qualitative Research 14(3):341-52.

Setiawan, Galih Katon dan Khotimah. 2018. "Politik Akomodif Dalam Masyaralat Multi Agama.” The Journal of Society and Media 3(1).

Hall, Kira, Donna M. Goldstein, and Matthew Bruce Ingram. 2016. "The Hands of Donald Trump: Entertainment, Gesture, Spectacle." HAU: Journal of Ethnographic Theory 6(2):71-100. 


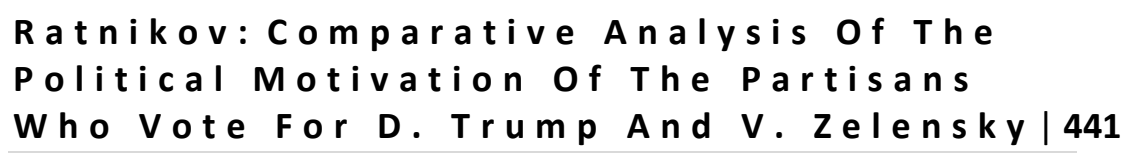

Hochschild, Arlie Russell. 2016. "The Ecstatic Edge of Politics: Sociology and Donald Trump." Contemporary Sociology 45(6):683-89.

Hochschild, Arlie Russell. 2018. Strangers in Their Own Land: Anger and Mourning on the American Right. The New Press.

Kennedy, Courtney, Mark Blumenthal, Scott Clement, Joshua D. Clinton, Claire Durand, Charles Franklin, Kyley McGeeney, Lee Miringoff, Kristen Olson, and Douglas Rivers. 2018. "An Evaluation of the 2016 Election Polls in the United States." Public Opinion Quarterly 82(1):1-33.

Kvale, Steinar. 2006. "Dominance through Interviews and Dialogues." Qualitative Inquiry 12(3):480-500.

De la Torre, Carlos. 2017. "Trump's Populism: Lessons from Latin America." Postcolonial Studies 20(2):187-98.

Lipset, Seymour Martin. 1955. "The Radical Right: A Problem for American Democracy." The British Journal of Sociology 6(2):176-209.

Mucciaroni, Gary. 1992. "The Garbage Can Model \& the Study of Policy Making: A Critique." Polity 24(3):459-82.

Norris, Pippa and Ronald Inglehart. 2019. Cultural Backlash: Trump, Brexit, and Authoritarian Populism. Cambridge University Press.

Oliver, J. Eric and Wendy M. Rahn. 2016. "Rise of the Trumpenvolk: Populism in the 2016 Election." The ANNALS of the American Academy of Political and Social Science 667(1):189-206.

Olney, Peter. 2018. “Trump's Triumph, Labor Resistance?” Pp. 63-69 in New Labor Forum. Vol. 27. SAGE Publications Sage CA: Los Angeles, CA.

Pandiangan, Andreas. 2018. "Kelompok Penyelenggara Pemungutan Suara (KPPS) Pemilu 2019, Tanggung Jawab Dan Beban Kerja.” The Journal of Society and Media 3(1).

Peisakhin, Leonid and Arturas Rozenas. 2018. "Electoral Effects of Biased Media: Russian Television in Ukraine." American Journal of Political Science 62(3):535-50.

Pettigrew, Thomas F. 2017. "Social Psychological Perspectives on Trump Supporters.” Journal of Social and Political Psychology 5(1):107-16.

Pierson, Paul. 2017. “American Hybrid: Donald Trump and the Strange Merger of Populism and Plutocracy." The British Journal of Sociology 68:S105-19.

Praveen, Kumar. 2020. “A Geopolitical Study of the Indo-Pacific Throught the 
Theories of Ancient East and Modern West." The Journal of Society and Media 4 (1).

Wang, Yu, Yang Feng, Zhe Hong, Ryan Berger, and Jiebo Luo. 2017. "How Polarized Have We Become? A Multimodal Classification of Trump Followers and Clinton Followers.” Pp. 440-56 in International Conference on Social Informatics. Springer.

Wellman, Elizabeth Iams, Susan D. Hyde, and Thad E. Hall. 2018. "Does Fraud Trump Partisanship? The Impact of Contentious Elections on Voter Confidence." Journal of Elections, Public Opinion and Parties 28(3):330 48.

Whitehead, Andrew L., Samuel L. Perry, and Joseph O. Baker. 2018. "Make America Christian Again: Christian Nationalism and Voting for Donald Trump in the 2016 Presidential Election." Sociology of Religion 79(2):14771. 